\title{
EVIDENCE OF ACTIVE HERPESVIRUS 6 (VARIANT-A) INFECTION IN PATIENTS WITH LYMPHADENOPATHY IN BELÉM, PARÁ, BRAZIL
}

\author{
Ronaldo B. FREITAS, Maria R. FREITAS \& Alexandre C. LINHARES
}

\begin{abstract}
SUMMARY
A total of 323 patients with lymphadenopathy were selected in Belém, Brazil, between January 1996 and December 2001, and screened for the presence of human herpesvirus-6 (HHV-6) IgM- and- IgG antibodies by enzyme-linked immunosorbent assay (ELISA). When seroprevalence is analyzed by gender, similar rates are found for female (60.6\%) and male (55.7\%) individuals. Seventy-seven (23.8\%) patients were HHV-6-IgM-and- IgG-positive (IgM+ subgroup), with positivity rates of $29.7 \%$ and $17.7 \%$ (p $=0.0007)$ for female- and male individuals, respectively. Sera from a subgroup $(n=120)$ of these subjects, with high HHV-6 antibody levels (either IgM+ or IgG+ reactivities), were subsequently processed for the presence of HHV-6 DNA by polymerase chain reaction $(\mathrm{PCR}) /$ nested PCR. Active infections (IgM+ and/or IgG+ high levels specific antibodies plus detection of viral DNA) were diagnosed in 20/77 (20.0\%) and 8/43 (18.6\%); subgroup of the 120 individuals suspected of having HHV-6 suggestive recent infection. All (n = 28) cases of active infection were found to be associated with HHV-6 variant-A (HHV-6A), as detectable by PCR/nested PCR, using variant-specific primer that amplify regions of 195 base pairs (bp) (HHV-6A) and 423 bp (HHV-6B). Rates of HHV-6 DNA detection between female and male patients were similar ( $\mathrm{p}>0.05)$ in the IgM+ and IgG+ groups: $20.4 \%$ versus $35.7 \%$ and $25.0 \%$ versus $13.0 \%$, respectively. HHV-6 DNA was detected across $\leq 5$ through 41-50-year age-groups for patients whose serum samples were IgM+, with rates ranging from $7.7 \%$ (female subjects aged $\leq 5$ years) to $80.0 \%$ (male, 11-20 years). Among patients whose serological status was IgG+, HHV-6 DNA was detected in $\leq 5,6-10,21-30$ and $>50$ age-groups at rates that ranged from $15.4 \%$ (male, $\leq 5$ years of age) to $100.0 \%$ (female aged 11-20 years). Swelling cervical lymph nodes were the most common sign, accounting for $9(32.0 \%)$ cases in each gender group. Among patients $(\mathrm{n}=28)$ with active infection by HHV-6A variant, duration of symptoms lasted 1-5 days in $35.7 \%$ of subjects, whereas in $64.3 \%$ of them the disease lasted 6-20 days. Our data suggest that it is worth seeking for HHV-6 infection whenever a patient (infant or adult) presents with lymphadenopathy as a prominent symptom in the course of an acute febrile illness.
\end{abstract}

KEYWORDS: Herpesvirus-6; Variant-A; Lymphadenopathy.

\section{INTRODUCTION}

Human herpesvirus $=6$ (HHV-6) is largely recognised as an ubiquitous virus that infects most persons up to the age of 2 years ${ }^{46}$. It was first isolated in 1986 by SALAHUDIN et al. ${ }^{50}$, from patients with lymphoproliferative disorders or acquired immunodeficiency syndrome. HHV-6 composes the Roseolovirus genus of the betaherpesvirus subfamily ${ }^{19,49}$. Two distinct variants (HHV-6A and HHV-6B) are currently recognised, with different genetic, biological and immunological properties $^{1,19}$. The HHV-6B appears to be isolated more frequently than HHV-6A from blood, except in patients with AIDS $^{2}$.

While HHV-6A has been obtained primarily from adults with chronic illnesses ${ }^{1,5}$, HHV-6B strains have mostly been isolated from infants with exanthem subitum (ES) (roseola infantum, sixth disease) and other paediatric febrile illnesses, including lymphadenopathy ${ }^{18,31,48,52}$. Since virtually all children become infected early life, primary HHV-6 infections among adults are rare events. Whenever these latter conditions occur, however, clinical findings such as lymphadenopathy ${ }^{38,44,53}$, heterophilenegative mononucleosis ${ }^{3,45}$ and hepatitis ${ }^{21}$ are likely to result. In most of the primary infections by HHV-6 the clinical symptoms are high fever and a rough skin rash, that is, the typical exanthema subitum; convulsions may also be present in those more severe cases. Primary infection in adults is not yet fully characterised, but a variety of clinical conditions have been described, including lymphoproliferative disorders ${ }^{6,7}$. On the other hand, reactivation may cause severe disease in immunocompromised patients and has also been reported to occur without symptoms in immunocompetent individuals ${ }^{26}$. The HHV-6A variant was found to be the predominant variant present in the lymph node biopsies from the HIV-infected patients ${ }^{15,34}$. 
In vivo HHV-6 replication has been demonstrated in a variety of cells including lymphocytes, macrophages, histiocytes, and endothelial/ epithelial cells; $\mathrm{CD}^{+}$lymphocytes appear to be the main target cells for HHV-6 ${ }^{9,10,13,43,44}$. The frequent detection of HHV-6 antigen/DNA in salivary glands ${ }^{22,36}$, lymph node tissues ${ }^{38}$, neurons and glial cells of the brain ${ }^{12}$ suggests that HHV-6 can either persistently infect cells or establish latency with potential subsequent reactivation. It has been reported that saliva is likely to play a major role in horizontal transmission of HHV-6, leading to the widespread of viral infection ${ }^{30}$. Consequently, serological studies have in general shown that nearly $100 \%$ of infants become infected before the age of 3 years ${ }^{8,46}$. In addition to this, large serosurveys conducted elsewhere, reported HHV-6 seroprevalence rates of 80 to $95 \%$ in healthy adolescents and adults ${ }^{40,51,59}$. In Northeastern Brazil, HHV-6 seroprevalence rates of $76.5 \%-77.2 \%$ were reported by LINHARES et $a l^{41}$ among Brazilian and Japanese immigrants. Similar surveys were subsequently conducted in the Amazon region of Brazil, yielding prevalence rates that ranged from $5.4 \%$ to $14.9 \%$ among Amerindians ${ }^{25}$, and from $75.0 \%$ to $100.0 \%$ in urban communities ${ }^{23}$.

This study focussed on cases of lymphadenopathy occurring in Belém, Pará, Brazil for which a diagnosis could not be achieved following a routine screening for those potentially most common causative infectious agents of this clinical condition. Further assays were then extended to HHV-6 and specific results are discussed herein.

\section{MATERIALS AND METHODS}

This was a retrospective study in which serum samples obtained from 323 patients with lymphoproliferative syndromes were examined for HHV-6 infection. These subjects had been referred by local physicians to the Virology Section of Instituto Evandro Chagas, Belém, Brazil, during the period of January 1996 to December 2001 for serological diagnosis. Patients enrolled in this study $(n=323)$ were selected from a total of 4,154 subjects with fever and lymphadenopathies who tested negative for the following agents: rubella, cytomegalovirus, EpsteinBarr virus, Toxoplasma gondii, and Brucella spp. All patients presented with an acute disease of moderate severity, mainly characterised by fever and lymphadenopathy. We did not include those patients with skin rash, as well as those lymphoproliferative disorders affecting immunosuppressed individuals. Study subjects (of whom 165 were female) were aged between 6 months and 78 years (mean, 19 years) at the time of blood sampling. Acute-phase blood samples were taken at presentation to the Institute, and sera were kept frozen at $-20{ }^{\circ} \mathrm{C}$ until they were processed.

The detection of IgM and IgG antibodies to HHV-6 was performed using a commercial enzyme-linked immunosorbent assay (ELISA) developed by PANBIO ${ }^{\mathrm{TM}}$ (East Brisbane, Australia). This is a system that includes solid-phase wells coated with HHV-6-infected cells, essentially as described elsewhere ${ }^{4,16,47}$. For the determination of HHV-6 immunoglobulin $\mathrm{M}(\mathrm{IgM})$ sera were tested at single 1:100 (v/v) dilutions, with previous removal of $\mathrm{IgG}$. This eliminates the interference phenomenon if rheumatoid factor is present in serum. All samples yielding optical density (OD) values which are at least twice the mean absorbance of the "cut off" were regarded as suggestive of recent HHV6 infection; this corresponds to $>20$ IgM PANBIO units. A subgroup (n $=120)$ of subjects among study patients with HHV-6 IgM+ $(>20$ PANBIO units for $\mathrm{IgM}$ ) or $\mathrm{IgG}+(\geq 50$ PANBIO units for $\mathrm{IgG})$ results were selected for HHV-6 DNA detection using a two-step polymerase chain reaction (PCR), as reported before ${ }^{35,53}$. First amplification was carried out using a mixture of external oligonucleotides primers designated as EX1 and EX2, followed by a second amplification cycle (the nested PCR) that includes a mixture of internal primers IN3 and IN4. A mixture including $1.5 \mathrm{mM} \mathrm{MgCl}_{2} 0.5 \mu \mathrm{M}$ of each primer, 2.5 units of Taq DNA polymerase (GIBCO-BRL) in the final concentration. Temperatures were used as follows: one initial cycle at $94^{\circ} \mathrm{C}$ for $5 \mathrm{~min}$, 40 cycles of denaturalization at $94^{\circ} \mathrm{C}$ for one min, annealing at $55^{\circ} \mathrm{C}$ for one min, and extension at $72^{\circ} \mathrm{C}$ for $1.5 \mathrm{~min}$, with a single final extension step at $72{ }^{\circ} \mathrm{C}$ for five min. Active HHV-6 infections were defined as the presence of $\operatorname{IgM}$ or/and high $\operatorname{IgG}$ antibody levels ( $\geq 50$ PANBIO units) plus DNA detection.

Variant-specific primers were used for PCR/nested PCR amplification, targeting two distinct regions of the HHV-6 genome of $195 \mathrm{bp}$ and $423 \mathrm{bp}$ for variants $\mathrm{A}$ and $\mathrm{B}$, respectively ${ }^{57}$.

Conventional ELISA and immunofluorescence indirect assays were used for the detection of both IgM and IgG to rubella, Epstein-Barr virus, cytomegalovirus and Toxoplasma gondii, as described before ${ }^{11,14,17,37}$. Only 28 samples were tested by standard seroagglutination to detect Brucella spp antibodies.

Statistical analysis was done with EPI-INFO software, version 6.0 (Atlanta, GA, USA). Comparison of rates between groups was made with the Mantel-Haenszel chi-square test of association or, if assumptions required for the chi-square test were not met, with Fisher's exact test. Siqnificance was defined as $\mathrm{p}<0.05$.

\section{RESULTS}

Overall, $188(58.2 \%)$ of the 323 patients had HHV-6-specific IgM and/or IgG antibodies in their sera, whereas 135 (41.8\%) subjects were found to be IgM- and- IgG-seronegative (Table 1). Serological status as defined by IgG+ was identified in 111 patients. Similar rates of HHV-6 antibodies (IgM and/or IgG) were noted for female and male subjects: $60.6 \%$ versus $55.7 \%$, respectively. Seventy-seven (23.8\%) patients were HHV-6 IgM- and- IgG-positive (IgM+ subgroup), with positivity rates of $29.7 \%$ and $17.7 \%(p=0.0007)$ for female- and- male individuals, respectively. No significant differences $(\mathrm{p}>0.05)$ across $\leq 5$ through 41-50-year age-groups were noted when prevalence rates of HHV-6 IgM+ antibodies for female and male subjects are compared. Seropositivity rates also did not differ significantly when gender groups are compared for HHV-6 IgG+ patients aged $\leq 5$ years and 11-20 to $>50$ years; a significant difference $(p=0.04)$ was observed between female and male patients belonging to the 6-10-year age-group. Sera from 120 patients with presumptive recent infections with $\operatorname{IgM}+(n=77)$ or $\operatorname{IgG}+(n=43)$ specific antibodies, were assessed for the presence of viral DNA by PCR and nested-PCR, as demonstrated in Table 2. HHV-6 DNA was amplified from the serum of 20/77 (25.9\%) IgM+ patients and from 8/43 (18.6\%) subjects whose serum samples reacted IgG+. There was no statistically significant difference $(\mathrm{p}>0.05)$. Rates of HHV-6 DNA detection between female and male patients were similar $(\mathrm{p}>0.05)$ in the IgM+ and IgG+ groups: $20.4 \%$ versus $35.7 \%$ and $25.0 \%$ versus $13.0 \%$, respectively. HHV-6 DNA was detected across $\leq 5$ through 41-50-year age-groups for patients whose serum samples were IgM+, with rates ranging from $7.7 \%$ (female subjects aged $\leq 5$ years) to $80.0 \%$ (male, $11-20$ years). 
Table 1

Detection of antibodies to HHV-6 in patients with lymphadenopathies. Belém, Brazil, 1996-2001

\begin{tabular}{|c|c|c|c|c|c|}
\hline \multirow{2}{*}{\multicolumn{2}{|c|}{ Age(years)/sex }} & \multirow{3}{*}{$\begin{array}{c}\begin{array}{c}\text { Total } \\
\text { tested }\end{array} \\
44\end{array}$} & \multicolumn{3}{|c|}{ Serological status, n (\%) } \\
\hline & & & \multirow{2}{*}{$\begin{array}{l}\text { IgM+ * } \\
13(29.5)\end{array}$} & \multirow{2}{*}{$\begin{array}{l}\text { IgG+ } \\
19(43.2)\end{array}$} & \multirow{2}{*}{$\begin{array}{l}\text { IgM-IgG- } \\
12(27.3)\end{array}$} \\
\hline$\leq 5$ & $\mathrm{~F}$ & & & & \\
\hline & M & 46 & $8(17.4)$ & $19(41.3)$ & $19(41.3)$ \\
\hline \multirow[t]{2}{*}{$6-10$} & $\mathrm{~F}$ & 28 & $10(35.7)$ & $7(25.0)^{\mathrm{c}}$ & 11(39.3) \\
\hline & M & 36 & $6(21.4)$ & $18(50.0)^{\mathrm{d}}$ & $12(33.3)$ \\
\hline \multirow[t]{2}{*}{$11-20$} & $\mathrm{~F}$ & 26 & $10(38.5)$ & $10(38.4)$ & $4(23.5)$ \\
\hline & M & 17 & $5(29.4)^{\mathrm{d}}$ & $8(47.1)$ & $4(23.5)$ \\
\hline \multirow[t]{2}{*}{$21-30$} & $\mathrm{~F}$ & 24 & $7(29.2)$ & $4(16.7)$ & $13(54.2)$ \\
\hline & M & 16 & $3(18.8)$ & $3(18.8)$ & $10(41.7)$ \\
\hline \multirow[t]{2}{*}{$31-40$} & $\mathrm{~F}$ & 14 & $2(14.3)$ & $1(7.1)$ & 11(78.6) \\
\hline & M & 15 & $2(13.3)$ & $3(20.0)$ & $10(66.7)$ \\
\hline \multirow[t]{2}{*}{$41-50$} & $\mathrm{~F}$ & 17 & $5(29.4)$ & $7(41.2)$ & $5(29.4)$ \\
\hline & M & 18 & $4(22.2)$ & $4(22.2)$ & $10(55.6)$ \\
\hline \multirow[t]{2}{*}{$>50$} & $\mathrm{~F}$ & 12 & $2(16.7)$ & $3(25.0)$ & $7(58.3)$ \\
\hline & M & 10 & $0(0.0)$ & $5(50.0)$ & $5(50.0)$ \\
\hline \multirow[t]{2}{*}{ Subtotal } & $\mathrm{F}$ & 165 & $49(29.7)^{\mathrm{a}}$ & $51(30.9)$ & $65(39.4)$ \\
\hline & M & 158 & $28(17.7)^{\mathrm{b}}$ & $60(38.0)$ & $70(44.3)$ \\
\hline Total & & 323 & $77(23.8)^{\mathrm{e}}$ & $111(34.4)^{\mathrm{f}}$ & $135(41.8)$ \\
\hline
\end{tabular}

*IgM detection (> 20 Panbio units); a vs b Significant difference between the results $(\mathrm{p}=0.0007) ;{ }^{\mathrm{c} v \mathrm{~d} d}$ Significant difference between the results $(\mathrm{p}=0.04)$; e $+\mathrm{f}=58.2 \%$ (overall seroprevalence rate)
Among patients whose serological status was IgG+, HHV-6 DNA was detected in $\leq 5,6-10,21-30$ and $>50$ age-groups at rates that ranged from $15.4 \%$ (male, $\leq 5$ years of age) to $100.0 \%$ (female aged $21-30$ years).

Figure 1 shows the anatomical sites of enlarged lymph nodes observed in 28 patients with active HHV-6 infection, according to sex and duration of these clinical signs in days. Overall, lymph node swelling was noted at similar rates in female $(15,53.6 \%)$ - and - male $(13,46.4 \%)$ patients with active HHV-6 infection caused by variant A. Reactive cervical lymph nodes were predominant, affecting 9 (32.0\%) patients of each gender group. In smaller proportions, occipital, retroauricular, axillary and inguinal enlarged lymph nodes were observed. As for the duration, symptoms lasted $1-5$ days in $35.7 \%$ of the individuals, whereas in $64.3 \%$ of them the disease lasted 6-20 days. Figure 2 illustrates the nested-PCR products with molecular weights matching those for HHV$6 \mathrm{~A}$ variant are present for 3 of the 28 serum samples from patients with active infections. No positive results were obtained from testing sera for

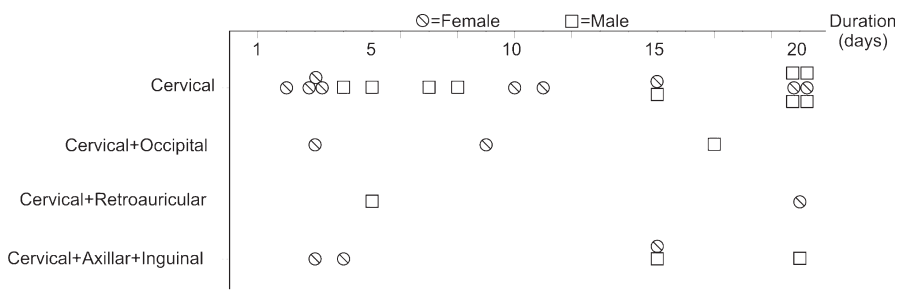

$(\otimes / \square)$ Each circle/square, one case

Fig. 1 - Localization and duration of the lymphadenopathies in cases of active HHV-6A infections, according to sex, in 28 patients. Belém, Brazil, 1996-2001.

Table 2

Distribution of active HHV-6 infections associated with lymphadenopathies, according to sex and age. Belém, Brazil, 1996-2001

\begin{tabular}{|c|c|c|c|c|c|c|c|}
\hline \multirow{2}{*}{\multicolumn{2}{|c|}{ Age(years)/sex }} & \multirow{3}{*}{$\begin{array}{c}\begin{array}{c}\text { Total } \\
\text { tested }\end{array} \\
13\end{array}$} & \multirow{2}{*}{\multicolumn{2}{|c|}{$\operatorname{IgM}+(\%)$}} & \multirow{3}{*}{$\begin{array}{c}\begin{array}{c}\text { Total } \\
\text { tested }\end{array} \\
10\end{array}$} & \multirow{2}{*}{\multicolumn{2}{|c|}{$\operatorname{IgG+}{ }^{* *}(\%)$}} \\
\hline & & & & & & & \\
\hline$\leq 5$ & $\mathrm{~F}$ & & $\frac{\text { DNA+ }}{1(7.7)}$ & $\frac{\text { DNA- }}{12(92.3)}$ & & $\frac{\text { DNA+ }}{3(30.0)}$ & $\frac{\text { DNA- }}{7(70.0)}$ \\
\hline & $\mathrm{M}$ & 8 & 1(12.5) & $7(87.5)$ & 13 & $2(15.4)$ & 11(84.6) \\
\hline \multirow[t]{2}{*}{$6-10$} & $\mathrm{~F}$ & 10 & $5(20.0)$ & $5(50.0)$ & 4 & $1(25.0)$ & $3(75.0)$ \\
\hline & $\mathrm{M}$ & 6 & $1(16.7)$ & $5(83.3)$ & 5 & $0(0)$ & $5(100.0)$ \\
\hline \multirow[t]{2}{*}{$11-20$} & $\mathrm{~F}$ & 10 & $2(20.0)$ & $8(80.0)$ & 3 & $0(0)$ & $3(100.0)$ \\
\hline & $\mathrm{M}$ & 5 & $4(80.0)$ & $1(20.0)$ & 0 & $0(0)$ & $0(0)$ \\
\hline \multirow[t]{2}{*}{$21-30$} & $\mathrm{~F}$ & 7 & $1(14.3)$ & $6(85.0)$ & 1 & $1(100.0)$ & $0(0)$ \\
\hline & $\mathrm{M}$ & 3 & $0(0)$ & $3(100.0)$ & 3 & $0(0)$ & $3(100.0)$ \\
\hline \multirow[t]{2}{*}{$31-40$} & $\mathrm{~F}$ & 2 & $1(50.0)$ & $1(50.0)$ & 0 & $0(0)$ & $0(0)$ \\
\hline & $\mathrm{M}$ & 2 & $1(50.0)$ & $1(50.0)$ & 0 & $0(0)$ & $0(0)$ \\
\hline \multirow[t]{2}{*}{$41-50$} & $\mathrm{~F}$ & 5 & $0(0)$ & $5(100.0)$ & 2 & $0(0)$ & $2(100.0)$ \\
\hline & $\mathrm{M}$ & 4 & $3(75.0)$ & $1(25.0)$ & 0 & $0(0)$ & $0(0)$ \\
\hline \multirow[t]{2}{*}{$>50$} & $\mathrm{~F}$ & 2 & $0(0)$ & $2(100.0)$ & 0 & $0(0)$ & $0(0)$ \\
\hline & $\mathrm{M}$ & 2 & $0(0)$ & $0(0)$ & 2 & $1(50.0)$ & $1(50.0)$ \\
\hline \multirow[t]{2}{*}{ Subtotal } & $\mathrm{F}$ & 49 & $10(20.0)$ & $39(79.6)$ & 20 & $5(25.0)$ & $15(75.0)$ \\
\hline & M & 28 & $10(35.7)$ & $18(64.3)$ & 23 & $3(13.0)$ & $20(86.9)$ \\
\hline \multicolumn{2}{|l|}{ Total } & 77 & $20(26.0)^{\mathrm{a}}$ & $57(74.0)$ & 43 & $8(18.6)^{b}$ & $35(81.4)$ \\
\hline
\end{tabular}

* A total of 203 serum samples not screened by PCR/nested PCR.; **IgG detection ( $\geq 50$ Panbio units); $\mathrm{a}+\mathrm{b}=44.6 \%$ (overall percentage of active HHV-6 infections) 


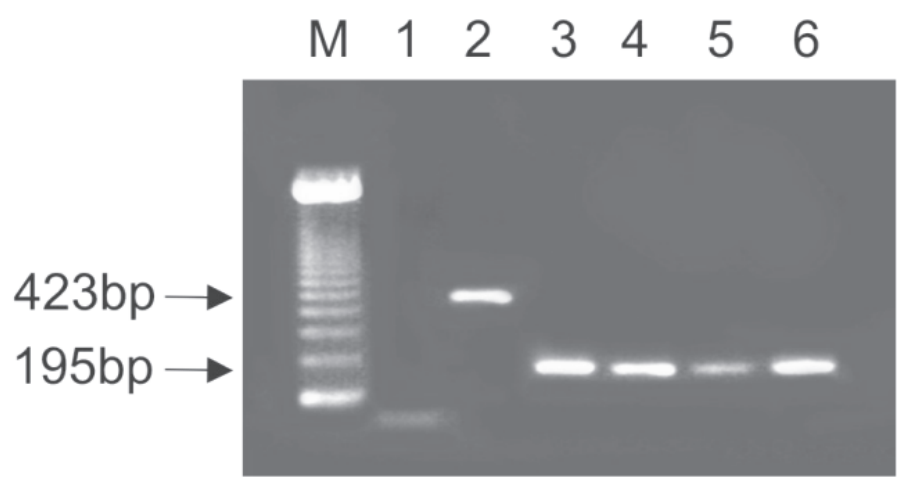

Fig. 2 - Agarose gel electrophoresis of nested PCR-amplified HHV-6 DNA of 6 serum samples, with variant-A (195 bp) and variant-B (423 bp) stained with ethidium bromide and photographed under U.V light. Lanes 1, negative control; lane 2, HHV-6B control; lane 3, HHV-6A control; lanes 4-6, displays HHV-6A positive sera; M denotes molecular-weight.

potential pathogens other than HHV-6 that might be involved in aetiology of the lymphadenopathies.

\section{DISCUSSION}

The present analysis of the HHV-6 serological status of $n=323$ patients with lymphadenopathy of previously unknown aetiology provided evidence that this herpesvirus may play a role as a cause for this clinical condition, as already reported elsewhere ${ }^{3}$. This assumption is based on the findings showing that about one-third of these patients had serological suggestive evidence of recent HHV-6 infection, that is, their sera reacted either $\mathrm{IgM}+$ or $\mathrm{IgG}+$ (high $\mathrm{IgG}$ levels) when tested for the presence of HHV-6 antibodies by ELISA. The proposed association between lymphadenopathy and HHV-6 infection in the present study is strengthened by the detection of HHV-6 DNA, by PCR ${ }^{30,53}$ in 28 subjects among 120 patients whose sera were indicative of active HHV-6 infection. Although focussing on a specific group of patients suffering from lymphoproliferative disorders, the present study allows for a reappraisal of HHV-6 seroprevalence in Belém, Pará, Brazil, an issue that has been assessed in previous local surveys conducted by FREITAS \& LINHARES ${ }^{23}$. The overall prevalence of HHV-6 antibody in the present study $(58.2 \%)$ was found to be lower than that yielded before for the "normal" population of Belém, Brazil, $90.0 \%{ }^{23}$. Although this may have occurred by chance, it would be worth considering two other explanations for such a difference. First, in the previous, "normal" population-based survey $^{23}$, an indirect immunofluorescence assay was used that might be more sensitive than the ELISA employed to assess the serological status of patients with lymphadenopathy. We do not believe that false-positive results were obtained when using the IFI, because of the high specificity of the test used ${ }^{8,51}$. Second, it could be postulated that a proportion of selected patients who developed lymphadenopathy had indeed primary HHV-6 infection. An evidence that might possibly support the "primary infection" hypothesis is that more than $40 \%$ of patients with lymphadenopathy had no detectable HHV-6 antibodies of either IgM or IgG classes, in contrast with the only $10 \%$ antibody-negative proportion in the normal population ${ }^{23}$. Our study showed an overall higher HHV-6 antibody (IgM and/or IgG) rate in female than in male patients with lymphadenopathy in Belém (29.7\% versus $17.7 \%$, $\mathrm{p}=0.007$ ), in contrast with similar prevalence rates achieved when comparing female $(90.5 \%)$ and male $(89.3 \%)$ subjects of a previous "normal population" study in the same setting. It is likely that women are more frequently exposed to HHV-6, as a result of their close contact with infants who might develop ES and, therefore, act as a source of viral transmission to mothers and care-givers. Excretion of HHV-6 in saliva of infants with ES and their parents suggests this to be a source for transmission of HHV-6 infection ${ }^{55}$.

A major finding in our study was the detection of HHV-6A DNA in sera from patients with lymphadenopathy, a viral variant that has been associated mainly with active infections among immunocompromised individuals, namely HIV-positive patients ${ }^{2,7,18,34,42,57}$. Contrasting with these findings, our investigation has shown HHV-6A variant to be associated with apparently immunocompetent individuals. Of note, it has been reported that immunocompromised and immunocompetent subjects are usually associated with reactivation ${ }^{28,29}$ and primary infections ${ }^{32,45,54}$, respectively, whatever variant considered. Of note, latency and later reactivation are both biological properties attributable to HHV-6A and HHV-6B variants in cells and body tissues ${ }^{6,7,20,38,39}$. It seems plausible to point out that the detection of HHV-6 DNA in sera from our patients support the hypothesis of primary infection ${ }^{53,56}$. Several studies ${ }^{2,3,5,45}$ record that active HHV-6A infection occurs later in life when compared with HHV-6B infection. Indeed, the latter variant appears to infect mainly infants younger than 3 years ${ }^{24,33,58}$. It is noticeable, however, that this has not invariably happened among our study subjects. On the other hand, some authors ${ }^{2,18,50}$ have demonstrated that a peak incidence of the HHV-6A infection occurs during adolescence and adulthood a pattern which appears more compatible with that recorded in our investigation. In this regard, it should be pointed out that HHV-6A infection appeared to be less frequent in our children aged less than five years with lymphadenopathy.

Of interest, no cases of neurological disorders - even seizures among infants - were identified among our patients who were infected with HHV-6A, in spite of previous reports indicating that such A variant has a possible greater neurotropism than $\mathrm{HHV}-6 \mathrm{~B}^{27}$. In our investigation, the cervical lymph nodes were more affected in both sexes, as recorded in studies conducted elsewhere ${ }^{38,45}$. Although preliminary, our data suggest that it would be worth seeking for HHV-6 infection, whenever a patient (infant or adult) presents with lymphadenopathy as a prominent symptom in the course of an acute febrile illness.

\section{RESUMO}

\section{Evidência de infecção ativa por herpesvírus 6 (variante- A) em pacientes com linfadenopatia em Belém, Pará, Brasil}

Um total de 323 pacientes apresentando linfadenopatia foi selecionado em Belém, Pará, Brasil, entre janeiro de 1996 a dezembro de 2001 e, posteriormente, examinado quanto à presença de anticorpos IgM e IgG para o herpesvírus 6 (HHV-6), utilizando-se a técnica imunoenzimática (ELISA). Taxas similares são encontradas quando a soroprevalência é analisada nos indivíduos do sexo feminino $(60,6 \%)$ e masculino $(55,7 \%)$. Setenta e sete $(23,8 \%)$ pacientes apresentaram anticorpos IgM e IgG para o HHV-6 (subgrupo IgM+), com taxas de positividade de $29,7 \%$ e $17,7 \%$ ( $\mathrm{p}=0,0007)$ para indivíduos dos sexos feminino e masculino, respectivamente. Soros de um subgrupo $(n=120)$ desses indivíduos, com altos níveis de anticorpos $\operatorname{IgM}+$ ou $\mathrm{IgG}+$, foram subseqüentemente processados para detecção do DNA viral do HHV-6, 
através da reação em cadeia da polimerase (PCR) e do "nested" PCR. Infecções ativas (detecção de altos níveis de anticorpos IgM+ e/ou IgG+ específicos mais a presença de DNA viral) foram diagnosticadas em 20/ $77(26,0 \%)$ e $8 / 43(18,6 \%)$; subgrupo de 120 indivíduos com quadro sugestivo de infecção recente por HHV-6. Todos $(n=28)$ os casos de infecção ativa foram associados com variante A do HHV-6 (HHV-6A), detectada pela técnica de PCR/"nested" PCR, utilizando-se "primers" específicos que amplificam regiões de 195 pares de bases (pb) (HHV6A) e 423 pb (HHV-6B).Taxas de detecção do DNA do HHV-6 foram similares $(\mathrm{p}>0,05)$ em pacientes dos sexos feminino e masculino, no grupo IgM+e IgG+ com: $20,4 \%$ versus $35,7 \%$ e $25,0 \%$ versus $13,0 \%$, respectivamente. A detecção do DNA viral do HHV-6 ocorreu no grupo etário $\leq 5$ até o de 41-50 anos, nos pacientes cujas amostras de soro apresentaram presença de IgM+, com taxas variando de 7,7\% (mulheres do grupo $\leq 5$ anos) a $80,0 \%$ (homens, 11-20 anos). Acerca dos pacientes cujo "status" sorológico foi IgG+, o DNA do HHV-6 foi detectado nos grupos de $\leq 5,6-10,21-30$ e $>50$ anos, com taxas que variaram de $15,4 \%$ (homens, $\leq 5$ anos) a 100,0\% (mulheres, $11-20$ anos). $\mathrm{O}$ aumento dos linfonodos cervicais foi registrado como mais freqüente, ocorrendo em número de $9(32,0 \%)$ casos, tanto entre indivíduos do sexo masculino como naqueles do feminino. Entre os pacientes $(n=28)$ com infecção ativa pela variante A do HHV-6, a duração dos sintomas em $35,7 \%$ deles foi de 1-5 dias, enquanto em 64,3\% durou de 6-20 dias. Nossos dados sugerem ser importante investigar a infecção pelo HHV-6 entre os pacientes (crianças e adultos) portadores de linfadenopatia como manifestação clínica proeminente no curso das doenças agudas febris.

\section{ACKNOWLEDGMENTS}

We thank Dr. Elisabete O. Santos, Talita A.F. Monteiro and Marinete Póvoa for carrying out the serological tests for rubella, cytomegalovirus, Epstein-Barr virus and Toxoplasma gondii. We are grateful to Dr. Naimes O. Paiva for his help in performing the Brucella spp.

\section{REFERENCES}

1. ABLASHI, D.V.; AGUT, H.; BERNEMAN, Z. et al. - Human herpesvirus-6 strain groups: a nomenclature. Arch. Virol., 129: 363-366, 1993.

2. ABLASHI, D.V.; BALACHANDRAN, N.; JOSEPHS, S.F. et al. - Genomic polymorphism, growth properties, and immunologic variations in human herpesvirus6 isolates. Virology, 184: 545-552, 1991.

3. AKASHI, K.; EIZURU, Y.; SUMIYOSHI,Y. et al. - Brief report: severe infectious mononucleosis-like syndrome and primary human herpesvirus 6 infection in an adult. New Engl. J. Med., 329: 168-171, 1993.

4. ASANO, Y.; YOSHIKAWA, T.; SUGA, S. et al. - Enzyme-linked immunosorbent assay for detection of IgG antibody to human herpesvirus 6. J. med. Virol., 32: 119-123, 1990

5. AUBIN, J.T.; COLLANDRE, H.; CANDOTTI, D. et al. - Several groups among human herpesvirus 6 strains can be distinguished by Sourthern blotting and polymerase chain reaction. J. clin. Microbiol., 29: 367-372, 1991.

6. BORISCH, B.; ELLINGER, K.; NEIPEL, F. et al. - Lymphadenitis and lymphoproliferative lesions associated with the human herpes virus-6 (HHV-6). Virchows Arch. B cell. Path., 61: 179-187, 1991.

7. BOVENZI, P.; MIRANDOLA, P.; SECCHIERO, P. et al. - Human herpesvirus 6 (variant A) in Kaposi's sarcoma. Lancet, 341: 1288-1289, 1993.
8. BRIGGS, M.; FOX, J.; TEDDER, R.S. et al. - Age prevalence of antibody to human herpesvirus 6. Lancet, 1: 1058-1059, 1988.

9. BURD, E.M. \& CARRIGAN, D.R. - Human herpesvirus 6 (HHV-6) associated dysfunction of blood monocytes. Virus Res., 29: 79-90, 1993.

10. BURD, E.M.; KNOX, K.K. \& CARRIGAN, D.R. - Human herpesvirus-6 associated suppression of growth factor-induced macrophage maturation in human bone marrow cultures. Blood, 81: 1645-1650, 1993.

11. CAMARGO, M.E.; LESER, P.G. \& LESER, W.S.P. - Diagnostic information from serological tests in human toxoplasmosis. I. A comparative study of hemagglutination, complement fixation, IgG- and IgM-immunofluorescence tests in 3,752 serum samples. Rev. Inst. Med. trop. S. Paulo, 18: 215-226, 1976.

12. CHALLONER, P.B.; SMITH, K.T.; PARKER, J.D. et al. - Plaque-associated expression of human herpesvirus 6 in multiple sclerosis. Proc. nat. Acad. Sci. (Wash.), 92 7440-7444, 1995.

13. CHEN, M.; POPESCU, N.; WOODWORTH, C. et al. - Human herpesvirus 6 infects cervical epithelial cells and transactivates human papillomavirus gene expression. J. Virol., 68: 1173-1178, 1994.

14. CHERNESKY, M.A.; WYMAN, L.; MAHONY, J.B. et al. - Clinical evaluation of the sensitivity and specificity of a commercially available enzyme immunoassay for detection of rubella virus-specific immunoglobulin M. J. clin. Microbiol., 20: 400-404, 1984.

15. CORBELLINO, M.; LUSSO, P.; GALLO, R.C. et al. - Disseminated human herpesvirus 6 infection in AIDS. Lancet, 342: 1242, 1993.

16. DAHL, H.; LINDE, A.; SUNDQUIST, V.A. \& WAHREN, B. - An enzyme-linked immunosorbent assay for IgG antibodies to human herpes virus 6. J. virol. Meth., 29: 313-323, 1990.

17. DEBYSER, Z.; REYNDERS, M.; GOUBAU, P. \& DESMYTE, J. - Comparative evaluation of three ELISA techniques and indirect immunofluorescence assay for the serological diagnosis of Epstein-Barr virus. Clin. diagn. Virol., 8: 71-81, 1997.

18. DEWHURST, S.; McINTYRE, K.; SCHNABEL, K. \& HALL, C.B. - Human herpesvirus 6 (HHV-6) variant B accounts for the majority of symptomatic primary HHV-6 infections in a population of U.S. infants. J. clin. Microbiol., 31: 416-418, 1993.

19. DOMINGUEZ, G.; DAMBAUGH, T.R.; STAMEY, R.R. et al. - Human herpesvirus 6B genome sequence: coding sequence and comparison with human herpesvirus 6A. J. Virol., 73: 8040-8052, 1999.

20. DRAGO, F. \& REBORA, A. - The new herpesviruses: emerging pathogens of dermatological interest. Arch. Derm., 135: 71-75, 1999.

21. DUBEDAT, S. \& KAPPAGODA, N. - Hepatitis due to human herpesvirus-6. Lancet, 2: 1463-1464, 1989.

22. FOX, J.D.; BRIGGS, M.; WARD, P.A. \& TEDDER, R.S. - Human herpesvirus 6 in salivary glands. Lancet, 336: 590-593, 1990

23. FREITAS, R.B. \& LINHARES, A.C. - Prevalence of human herpesvirus 6 antibody in the population of Belém, Pará, northern Brazil. Trans. roy. Soc. trop. Med. Hyg., 91: 538-540, 1997.

24. FREITAS, R.B.; LINHARES, A.C.; OLIVEIRA C.S.; GUSMÃO, R.H. \& LINHARES, M.I. - Association of human herpesvirus 6 infection with exanthem subitum in Belém, Brasil. Rev. Inst. Med. trop. S. Paulo, 37: 489-492, 1995.

25. FREITAS, R.B.; LINHARES, M.I.S. \& LINHARES, A.C. - Prevalence of human herpesvirus 6 antibody isolated Amazonian Amerindian communities in Brazil. Trans. roy. Soc. trop. Med. Hyg., 88: 167-169, 1994.

26. FREITAS, R.B.; MONTEIRO, T.A.F. \& LINHARES, A.C. - Outbreaks of human-herpes virus 6 (HHV-6) infection in day-care centers in Belém, Pará, Brazil. Rev. Inst. Med. trop. S. Paulo, 42: 305-311, 2000. 
27. HALL, C.B.; CASSERTA, M.T.; SCHNABEL, K.C. et. al. - Persistence of human herpesvirus 6 according to site and variant: possible greater neurotropism of variant A. Clin. infect. Dis., 26: 132-137, 1998.

28. HALL, C.B.; LONG, C.E.; SCHNABEL, K.C. et al. - Human herpesvirus 6 infection in children. A prospective study of complication and reactivation. New Engl. J. Med., 331: 432-438, 1994.

29. IULIANO, R.; TROVATO, R.; LICO, S. et al. - Human herpesvirus-6 reactivation in a longitudinal study of two HIV-1 infected patients. J. med. Virol., 51: 259-264, 1997.

30. JARRET, R.F.; CLARK, D.A.; JOSEPHS, S.F. \& ONIONS, D.E. - Detection of human herpesvirus-6 DNA in peripheral blood and saliva. J. med. Virol., 32: 73-76, 1990.

31. KIMBERLIN, D.W. - Human herpesviruses 6 and 7: identification of newly recognized viral pathogens and their association with human disease. Pediat. infect. Dis. J., 17: 59-67, 1998.

32. KIRCHESCH, H.; MERTENS, T.; BURKHARDT, U. et al. - Seroconversion against human herpesvirus-6 (and other herpesviruses) and clinical illness. Lancet, 2: 273274, 1988.

33. KNOWLES, W.A. \& GARDNER, S.D. - High prevalence of antibody to human herpesvirus-6 and seroconversion associated with rash in two infants. Lancet, 2: 912-913, 1988.

34. KNOX, K.K. \& CARRIGAN, D.R. - Active HHV-6 infection in the lymph nodes of HIV infected patients: in vitro evidence that HHV-6 can break HIV latency. J. Acquir. Immun. Defic. Syndr. Retrov., 11: 370-378, 1996.

35. KONDO, K.; HAYAKAWA, Y.; MORI, H. et al. - Detection by polymerase chain reaction amplification of human herpesvirus 6 DNA in peripheral blood of patients with exanthem subitum. J. clin. Microbiol., 28: 970-974, 1990.

36. KRUEGER, G.R.F.; WASSERMANN, K.; DECLERCK, L.S. et al. - Latent herpesvirus6 in salivary and bronchial glands. Lancet, 336: 1255-1256, 1990.

37. LAZZAROTTO, T.; DALLA CASA, B.; CAMPISI, B. \& LANDINI, M.P. - Enzymelinked immunosorbent assay for the detection of cytomegalovirus-IgM: comparison between eight commercial kits, immunofluorescence and immunoblotting. J. clin. Lab. Anal., 6: 216-218, 1992.

38. LEVINE, P.H.; JAHAN, N.; MURARI, P.; MANAK, M. \& JAFFE, E.S. - Detection of human herpesvirus 6 in tissues involved by sinus histiocytosis with massive lymphadenopathy (Rosai Dorfman disease). J. infect. Dis., 166: 291-295, 1992.

39. LEVY, J.A. - Three new human herpesviruses (HHV-6, 7, and 8). Lancet, 349: 558-563, 1997.

40. LINDE, A.; DAHL, H.; WAHREN, B. et al. - IgG antibodies to human herpesvirus-6 in children and adults and in primary Epstein-Barr virus infections and cytomegalovirus infections. J. virol. Meth., 21: 117- 123, 1988.

41. LINHARES, M.I.S.; EIZURU, Y.; TATENO, S. \& MINAMISHIMA, Y. - Seroprevalence of human herpesvirus-6 infection in Brazilian and Japanese populations in the Northeast of Brazil. Microbiol. Immunol., 35: 1023-1027, 1991.

42. LUPPI, M.; MARASCA, R.; BAROZZI, P.; ARTUSI, T. \& TORELLI, G. - Frequent detection of human herpesvirus- 6 sequences by polymerase chain reaction in paraffinembedded lymph nodes from patients with angioimmunoblastic lymphadenopathy and angioimmunoblastic lymphadenopathy-like lymphoma. Leukemia Res., 17: 1003-1011, 1993

43. LUSSO, P.; MALNATI, M.; De MARIA, A. et al. - Productive infection of $\mathrm{CD}^{+}$and CD8 ${ }^{+}$mature human $\mathrm{T}$ cell populations and clones by human herpesvirus 6 . Transcriptional down-regulation of CD3. J. Immunol., 147: 685-691, 1991.
44. LUSSO, P.; SALAHUDDIN, S.Z.; ABLASHI, D.V. et al. - Diverse tropism of human $\beta$ lymphotropic virus (human herpesvirus 6). Lancet, 2: 743, 1987.

45. NIEDERMAN, J.C.; LIU, C.R.; KAPLAN, M.H. \& BROWN, N.A. - Clinical and serological features of human herpesvirus- 6 infection in three adults. Lancet, 2 : 817-819, 1988.

46. OKUNO, T.; TAKAHASHI, K.; BALACHANDRA, K. et al. - Seroepidemiology of human herpesvirus 6 infection in normal children and adults. J. clin. Microbiol., 27: 651-653, 1989.

47. PARKER, C.A. \& WEBER, J.M. - An enzyme-linked immunosorbent assay for the detection of IgG and IgM antibodies to human herpesvirus type 6. J. virol. Meth., 41: $265-276,1993$

48. PELLETT, P.E.; LINDQUESTER, G.J.; FEORINO, P. \& LOPEZ, C. - Genomic heterogeneity of human herpesvirus 6 isolates. Advanc. exp. Med. Biol., 278: 9-18, 1990 .

49. ROIZMANN, B.; DESROSIERS, R.C.; FLECKENSTEIN, B. et al. - The family Herpesviridae: an update. The Herpesvirus Study Group of the International Committee on Taxonomy of Viruses. Arch. Virol., 123: 425-449, 1992.

50. SALAHUDDIN, S.Z; ABLASHI, D.V.; MARKHAM, P.D. et al. - Isolation of a new virus, HBLV, in patients with lymphoproliferative disorders. Science, 234: 596-601, 1986.

51. SAXINGER, C.; POLESKY, H.; EBY, N. et al. - Antibody reactivity with HBLV (HHV6) in U.S. populations. J. virol. Meth., 21: 199-208, 1988.

52. SCHIRMER, E.C.; WYATT, L.S.; YAMANISHI, K. et al. - Differentiation between two distinct classes of viruses now classified as human herpesvirus 6. Proc. nat. Acad. Sci. (Wash.), 88: 5922-5926, 1991.

53. SECCHIERO, P.; CARRIGAN, D.R.; ASANO, Y. et al. - Detection of human herpesvirus 6 in plasma of children with primary infection and immunosuppressed patients by polymerase chain reaction. J. infect. Dis., 171: 273-280, 1995.

54. STETTNER-GLONING, R.; JAGER, G.; GLONING, H.; PONTZ, B.F. \& EMMRICH, P. - Lymphadenopathy in connection with human herpesvirus type 6 (HHV-6) infection. Clin.Invest., 70: 59-62, 1992.

55. SUGA, S.; YOSHIKAWA, T.; KAJITA, Y.; OZAKI, T. \& ASANO, Y. - Prospective study of persistence and excretion of human herpesvirus- 6 in patients with exanthem subitum and their parents. Pediatrics, 102: 900-904, 1998.

56. WARD, K.N.; PARADA, X.C.; PASSAS, J. \& THIRUCHELVAM, A.D. - Evaluation of the specificity and sensitivity of indirect immunofluorescence tests for IgG to human herpesvirus-6 and- 7. J. virol. Meth., 106: 107-113, 2002.

57. YALCIN, S.; KARPUZOGLU, T.; SULEYMANLAR, G. et al. - Human herpesvirus 6 and human herpesvirus 7 infections in renal transplant recipients and healthy adults in Turkey. Arch. Virol., 136: 183-190, 1994.

58. YAMANISHI, K.; OKUNO, T.; SHIRAKI, K. et al. - Identification of human herpesvirus 6 as a causal agent for exanthem subitum. Lancet, 1: 1065-1067, 1988.

59. YOSHIKAWA, T.; SUGA, S.; ASANO, Y.; YAZAKI, T. \& OZAKI, T. - Neutralizing antibodies to human herpesvirus 6 in healthy individuals. Pediat. infect. Dis. J., 9: 589-590, 1990.

Received: 18 June 2003

Accepted: 23 September 2003 